\title{
Henry Dale and the Discovery of Chemical Synaptic Transmission
}

\author{
Don Todman \\ School of Medicine, University of Queensland, Brisbane, Qld., Australia
}

\section{Key Words}

Henry Dale • Synaptic transmission • Neurohistory •

Nobel prize

\section{Abstract}

Henry Dale received the Nobel prize in physiology or medicine in 1936 with Otto Loewi for their research which proved chemical synaptic transmission in the peripheral nervous system. Subsequently there was an extended period of controversy between advocates of chemical and electrical transmission before the chemical process was established in the central and peripheral nervous system. This debate and its final resolution was one of the most crucial in the history of neuroscience in the 20th century.
\end{abstract}

Copyright $\odot 2008$ S. Karger AG, Basel

Henry Hallett Dale (1875-1968) was awarded the Nobel prize in physiology or medicine in 1936 with Otto Loewi for their research which established chemical synaptic transmission (fig. 1). Although neurotransmitters are now integral to brain science, the controversy between proponents of chemical and electrical transmission continued over a prolonged period. Henry Dale, a pharmacologist, was the principal advocate of chemical transmission whilst his most prominent adversary was the neurophysiologist John Eccles (1903-1997). Believing that transmission at synapses was too rapid to be a chemical process, Eccles considered that synaptic excitation

\section{KARGER \\ Fax +41613061234 \\ E-Mail karger@karger.ch}

www.karger.com (c) 2008 S. Karger AG, Basel 0014-3022/08/0603-0162\$24.50/0

Accessible online at: www.karger.com/ene

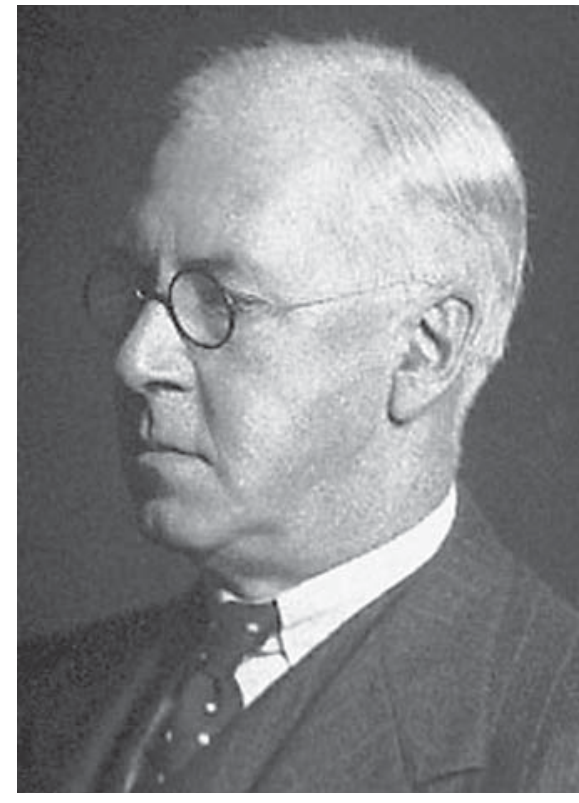

Fig. 1. Sir Henry Hallett Dale (1875-1968). The Nobel Foundation, with kind permission.

was electric. The prolonged period of debate through the 1940s and much of the 1950s was one of the most significant in the history of neuroscience in the 20th century [1]. Although Eccles' initial hypothesis was incorrect, his arguments led himself and others to perform key experiments which confirmed chemical transmission in the central and peripheral nervous system. 
Henry Dale was born in London in 1875 and attended the Leys School in Cambridge before completing his undergraduate course in natural sciences at Trinity College. He worked under John Langley as a Coutts-Trotter student from 1889 to 1900 before completing his medical degree at Saint Bartholomew's Hospital in 1903. He embarked on a career in laboratory research which began in Ernest Starling's laboratory at University College in London. It was here that he first met his lifelong friend and collaborator, Otto Loewi. After working for 4 months with Paul Ehrlich in Frankfurt, he returned to London to work at the Wellcome physiological research laboratories. Henry Wellcome, proprietor of Burroughs-Wellcome pharmaceutical company, offered him a position and later directorship. Although colleagues advised against a commercial appointment, he decided that his academic prospects were bleak and the opportunity of securing his own laboratory with a stable income was compelling [2]. By the end of his 10 years at Wellcome, he was internationally recognised as a major figure in experimental pharmacology.

In the early 1900s, research on adrenal gland extracts had demonstrated that they could simulate autonomic nerve stimulation. Thomas Elliott working at Cambridge proposed that adrenaline was released following sympathetic nerve stimulation whilst Walter Dixon reported a nerve transmitter resembling the chemical muscarine in the parasympathetic nervous system. John Langley postulated that within the autonomic nervous system, nerve terminals could secrete a variety of substances [3]. Although foundational to later research, the work lacked a cohesive model and many of the chemical substances used were not known to exist in the human body.

At the suggestion of Henry Wellcome, Dale's initial research was on the physiological effects of the fungus ergot, in which he discovered that extracts reversed the effect of adrenaline and the action of sympathetic nerves [4]. By 1910 his work on noradrenaline established that it had a stronger stimulating and weaker inhibitory activity than adrenaline. Noradrenaline appeared to be a more likely candidate as a chemical transmitter but Dale was cautious about extrapolating his findings as it was a synthetic agent and was not then known to exist in the body. His early research also included the discovery of the oxytocic action of pituitary extract and work on histamine in studies of anaphylaxis and shock.

In 1913 experiments with acetylcholine showed that intravenous injection inhibited the heartbeat of the cat. Through detailed studies, he showed that this purified substance produced the same effect as parasympathetic

Henry Dale and the Discovery of

Chemical Synaptic Transmission nerve stimulation or a muscarine-like reaction. As with noradrenaline, Dale was initially reluctant to suggest that acetylcholine may be a neurotransmitter.

In 1921, Otto Loewi, Professor of Pharmacology in Graz, Austria found evidence to support chemical mediation of nerve impulses. His experiments involved stimulating the vagus and sympathetic fibres to the frog's heart and isolating two substances which had different effects when applied to a second heart preparation. Loewi coined the terms 'Acceleransstoff' for the substance which simulated sympathetic stimulation and 'Vagusstoff', the substance which simulated vagal stimulation [5]. Henry Dale and colleagues working at Hampstead at the National Institute of Medical Research established through a series of experiments that 'Vagusstoff' was acetylcholine. They established for the first time that neurotransmitters were released not only to innervate smooth muscle but also at synapses in autonomic ganglia, sympathetic and parasympathetic.

By 1936 Dale and co-workers had confirmed that neurotransmitters were secreted at all peripheral synapses. Experiments using a leech muscle preparation provided additional information that acetylcholine was released at the neuromuscular junction. There was thus persuasive evidence for the chemical transmission in the peripheral nervous system with acetylcholine at autonomic preganglionic nerves and that postganglionic parasympathetic synapses are cholinergic and sympathetic synapses adrenergic. The culmination of this work was the award of the Nobel prize in 1936 for the 'discovery of chemical synaptic transmission'.

In his Nobel speech Dale revealed his characteristic humility by drawing attention to the important study of 1921 by his co-laureate Otto Loewi and attributed their recognition to his pioneering discoveries [6]. The speech also alluded to the possibility of chemical transmission in the central nervous system and highlighted the rich supply of acetylcholine in the basal ganglia. He concluded cautiously, 'I take the view however that we need a much larger array of well authenticated facts before we can theorize' [7].

Many neurophysiologists were quick to reject suggestions of chemical neurotransmission in the central nervous system. John Eccles was the chief proponent of electrical transmission believing that transmission at synapses was too rapid for a chemical process. John Fulton, like Eccles, a student of Sherrington at Oxford, was editor of the influential Journal of Neurophysiology in the 1940s and 1950s. In his 1949 textbook he strongly espoused the prevailing view, 'The idea of a chemical mediator released 
at the nerve ending and acting on a second neurone or muscle thus appeared to be unsatisfactory in many respects' [8].

Dale and Eccles were strong protagonists but also respectful and even humorous in their dialogues. They frequently exchanged letters and their work was often discussed prior to publication. A turning point in neurophysiology research came with the application of microelectrode studies which were utilised in Eccles' laboratories. His work initially in Sydney, Australia from 1937 and then Otago, New Zealand from 1944 to 1951 involved recording intracellular electrical responses produced by excitatory and inhibitory synapses. The work was presented in the Waynflete Lectures in Oxford in 1952 and published in the monograph The Neurophysiological Basis of Mind: The Principles of Neurophysiology [9]. The crucial experiment was conducted in August 1951 and the results were conclusive that the level of inhibition (hyperpolarisation) recorded within intracellular microelectrodes could not be induced electrically [10]. Eccles was an immediate convert to chemical transmission and wrote to Dale without delay. Dale later wrote that Eccles' conversion to a chemical explanation of inhibition in the spinal cord was like the conversion of Saul on the road to Damascus when 'the sudden light shone and the scales fell from his eyes' [11].

From 1952 to 1956 Eccles worked in Canberra at the Australian National University and, with numerous international collaborators, further elaborated the role of acetylcholine in inhibition. They demonstrated that col- lateral branches of spinal motor neurones released acetylcholine to excite the Renshaw cells in the spinal cord. Although opposition to chemical transmission persisted into the mid-1950s, the influence of Eccles, himself a Nobel laureate in 1963, was instrumental in securing the theory of chemical neurotransmitters. By the 1960s, the theory was integral to brain science and the emerging field of neuropharmacology. Although chlorpromazine and other psychotropic drugs were developed in the 1950s, a decade later their action and that of other new drugs was understood through the effect on neurotransmitters or their receptors.

During his lifetime Henry Dale was the recipient of many awards including the Presidency of the Royal Society (1940-1945), the Royal Society of Medicine (19481950) and public honours including the GBE (Knight Grand Cross, Order of the British Empire), the medal of Freedom (USA) and the Grand-Croix de l'Ordre de la Couronne (Belgium) [12]. His published works reveal the struggles and achievements over 30 years of research at the Wellcome laboratories and at the National Institute of Medical Research [13, 14]. The concept of chemical transmission developed in stages with at first strong opposing views held by Dale and other pharmacologists and Eccles and influential neurophysiologists. The resolution of this polarising debate is a remarkable chapter in the history of neuroscience. It illustrates the collaboration of exceptional scientists in different disciplines which finally answered the important question of how neurones communicate with one another.

\section{References}

1 Cook JS: 'Spark' vs. 'soup': a scoop for soup. News Physiol Sci 1986;1:206-208.

2 Dale HH: Some fifty years in British medical science; in Ingle DJ (ed): A Dozen Doctors: Autobiographical Sketches. Chicago, University of Chicago Press, 1963, pp 1-13.

3 Langley JN: On nerve endings and on excitable substances in cells. Proc R Soc Med 1906;78B:179-194.

4 Dale HH: On some physiological actions of ergot. J Physiol 1906;343:163-206.

5 Loewi O: The Ferrier Lecture: on problems connected with the principle of humoral transmission of nervous impulses. Proc $\mathrm{R}$ Soc 1935;118B:299-316.
6 Nobelprize.org, Sir Henry Dale Nobel Lecture. Available at http://nobelprize.org. Ac cessed on October 20, 2007.

7 Dale HH: Some recent extensions of the chemical transmission of the effects of nerve impulses; in Nobel Lectures 1922-1941. New York, Elsevier, 1965, pp 402-413.

8 Fulton JF: Physiology of the Nervous System, ed 3. New York, Oxford University Press, 1949.

9 Eccles JC: The Neurophysiological Basis of Mind: The Principles of Neurophysiology. Oxford, Oxford University Press, 1952.

10 Brock LG, Coombs JS, Eccles JC: The recording of potentials from motor neurones with an intracellular electrode. J Physiol 1952;117: 431-460.
-11 Eccles JC: From electrical to chemical transmission in the central nervous system. Notes Rec R Soc Lond 1976;30:219-230.

12 Nobelprize.org, Sir Henry Dale, The Nobel Prize in Physiology or Medicine 1936. Available at http://nobelprize.org. Accessed on October 20, 2007.

13 Dale HH: Adventures in Physiology with Excursions into Autopharmacology. London, Pergamon Press, 1954.

14 Dale HH: An Autumn Gleaning: Occasional Lectures and Addresses. London, Pergamon Press, 1954. 